\section{JURNAL MANAJEMEN \& BISNIS} KREATIF

Jurnal IImiah hasil penelitian dan Informasi IPTEKS Volume. 2 No.2 April 2017 - Sept 2017

\begin{tabular}{|c|}
\hline $\begin{array}{c}\text { Susunan Pengelola } \\
\text { SK. Rektor : 017/SK/A.4/X/2015 }\end{array}$ \\
\hline $\begin{array}{c}\text { Pelindung } \\
\text { Dr. H. Dedi Mulyadi, SE.,MM }\end{array}$ \\
\hline $\begin{array}{c}\text { Ketua Penyunting } \\
\text { Sari Marliani, SE.,MM }\end{array}$ \\
\hline $\begin{array}{c}\text { Dewan Penyunting } \\
\text { H. Tarpan Suparman S.Pd .M.Pd (UBP }\end{array}$ \\
\hline $\begin{array}{c}\text { Karawang) } \\
\text { Nelly Martini, SE.,MM } \\
\text { (Unsika) }\end{array}$ \\
\hline $\begin{array}{c}\text { H. Acim Supriadi, SE.,MM } \\
\text { (UBP Karawang) }\end{array}$ \\
\hline $\begin{array}{l}\text { Rahmat Hasbullah, SE.,M.Pd } \\
\text { (Unsika) }\end{array}$ \\
\hline $\begin{array}{c}\text { Abdul Yusuf, SE.,MM } \\
\text { (Unsika) }\end{array}$ \\
\hline $\begin{array}{c}\text { Yudin Wahyudin, SE.,MM } \\
\text { (STIE YPN) }\end{array}$ \\
\hline $\begin{array}{l}\text { Jajang Sugiat, SE.,MM } \\
\text { (STIE Yasa Anggana) }\end{array}$ \\
\hline $\begin{array}{c}\text { Yudi Suwandi, SE.,MM } \\
\text { (STIE EKUITAS) }\end{array}$ \\
\hline $\begin{array}{l}\text { Penyunting Pelaksana } \\
\text { Ajat Sudrajat, SE.,MM } \\
\text { Ina Ratnasari, SE.,MM }\end{array}$ \\
\hline $\begin{array}{c}\text { Sirkulasi dan Pemasaran } \\
\text { Chandra Zonyfar, S.Kom } \\
\text { Yogi Ginanjar } \\
\text { Alifya Nurzehan }\end{array}$ \\
\hline
\end{tabular}

Alamat :

LPPM Universitas Buana Perjuangan

Jl. H.S Ronggowaluyo Telukjambe Karawang

Telp/Fax : 0267-8403140

\section{Daftar Isi}

Pengaruh Disiplin dan Motivasi Terhadap Kinerja Pegawai Bidang Tata Ruang dan Permukiman pada Dinas Cipta Karya Kabupaten Karawang Sugkono $1-23$

Pengaruh pemberian insentif terhadap kinerja karyawan di pt. Sicpa peruri securink Ade Sofyan

$$
24-40
$$

Pengaruh pengembangan karir dan motivasi kerja terhadap kinerja penyuluh keluarga berencana (pkb) pada badan keluarga berencana dan pemberdayaan perempuan (bkbpp) kabupaten karawang Neneng Sofiyanti, R. Aditya Kristamtomo Putra $41-55$

Manfaat Wisata Tugu Kebulatan Proklamasi Di Rengasdengklok Karawang Bagi Masyarakat Lokal Sebagai Peluang Usaha Untuk Meningkatkan Taraf Hidup Sebagai Pedagang Kecil.

Rieke Retnosary $\quad 56-70$

Analisis Disiplin Kerja Terhadap Kinerja Pegawai Dinas Perikanan Dan Kelautan Kabupaten Karawang

Wanta

e-mail : jurnal.fbis@ubpkarawang.ac.id

Jurnal Manajemen \& Bisnis yang diterbitkan oleh LPPM Universitas Buana Perjuangan Karawang terbit dua kali dalam satu tahun (Oktober dan April). Jurnal Manajemen \& Bisnis adalah media untuk mempublikasikan karya ilmiah dan pertukaran informasi sebagai upaya peningkatan kualitas akademik bagi dosen, mahasiswa dan masyarakat umum. 